\title{
Влияние полиморфизмов гена UGT на скорость восстановления когнитивных функций после введения пропофола
}

\author{
Ушакова А. ${ }^{1 *}$, Шашкина Е. ${ }^{1}$, Воронина Е.Н. ${ }^{1,2}$, Черданцев С.В. ${ }^{1,2}$ \\ ${ }^{1}$ Специилизированный учебно-научный центр Новосибирского государственного университета, \\ Новосибирск, Россия \\ ${ }^{2}$ Региональный центр выявления и поддержки одаренных детей «Альтаир», Новосибирск, Россия \\ *a.ushakova2@school.nsu.ru
}

Ключевые слова: наркоз, УДФ-глюкуронозилтрансфераза (UDP-glucuronosyltransferase, UGT), $\mathrm{rt}-$ ПР, электрофорез

Мотиващия и цель: В настоящее время известно, что многие люди плохо переносят операции, включающие в себя наркоз. Многие пациенты воспринимают химические вещества с разными последующими симптомами. В современном мире лекарства назначают так, как если бы они одинаково хорошо работали у всех людей. Но из-за разного возраста, состояния здоровья, конституции тела, генетических различий и других факторов люди не всегда одинаково реагируют на лекарственную терапию, появляются побочные эффекты. Важно осуществлять поиск наследственных особенностей, которые влияют на эффекты лекарств, помогают практикующим врачам правильно подбирать препарат и дозировки к определенным пациентам, создавать новые лекарства - более безопасные и эффективные.

Нашей целью было изучить полиморфизмы и влияние генов UGT, которые отвечают за метаболизм и вывод ксенобиотиков в организме человека, и определить влияние на скорость восстановления когнитивных функций.

Meтоды $u$ алгоритмы: Для выявления полиморфизмов гена UGT мы использовали метод ПЦР real time. Для анализа и дальнейшей обработки результатов ПЦР real time использовали программу Bio-rad CFX. Провели анализ выявленных генотипов с предоставленными данными о реакции определенных пациентов на наркоз.

Результаты: Посредством проведения ПЦР real time гена UGT мы изучили полиморфизмы гена UGT в имеющихся образцах. В итоге из выборки численностью в 76 человек у нас выявилось 40 доминантных гомозигот по аллели дикого типа, 31 гетерозиготный представитель, который содержит как аллель дикого типа, так и мутантную аллель, и всего 5 гомозиготных рецессивных представителей, содержащих только мутантную аллель гена. Исследовали зависимость скорости восстановления когнитивных функций от генотипа пациента.

Заключение: Изучили полиморфизмы гена UGT в имеющихся образцах. Было замечено, что полиморфизмы генов UGT влияют на скорость восстановления когнитивных функций пациентов. 